\title{
How to Manage Classroom in College Teaching
}

\author{
Yu Liao \\ City College of Wuhan University of Science and Technology, Department of Business Management, \\ Wuhan, China \\ E-mail: tomliao-898@163.com
}

Keywords: Colleges and universities, Classroom management, Mode, Teaching method.

\begin{abstract}
With the gradual popularization of china's higher education, In recent years, The competition between various colleges and universities is becoming more and more fierce, the quality and brand become a magic weapon to win. In the course of teaching management, the problem of weak classroom management generally exists in our country. The strict management of students by teachers is the key to school management. Based on the analysis of the influencing factors of classroom management, this paper discusses the basic mode of classroom management and puts forward some measures on how to manage classroom in college teaching.
\end{abstract}

\section{Introduction}

Classroom management is a series of teaching behaviors for teachers to complete teaching tasks, regulate interpersonal relationships, harmonious teaching environment, and guide students to learn. Management classroom is the cornerstone of teaching activities, teachers must constantly improve classroom teaching management skills. In classroom teaching, in addition to the task of "teaching", teachers also have the task of "managing", that is, coordinating and controlling various teaching factors and their relations in the classroom to form an orderly whole. to ensure the smooth progress of teaching activities. This activity is commonly referred to as classroom management.

The tasks of classroom management are relatively complex. It is generally believed that classroom management includes classroom interpersonal management, classroom environment management, classroom discipline management and so on. The management of classroom interpersonal relationships refers to the management of teacher-student relations and peer relations in the classroom, including the establishment of good teacher-student relations, the establishment of group norms, and the creation of harmonious peer relations; Classroom environmental management refers to the management of the teaching environment in the classroom, including the arrangement of the physical environment and the construction of the psychosocial environment; Classroom discipline management refers to the formulation and implementation of classroom behavior norms and standards, and responds to students 'problem behaviors.

\section{Factors influencing classroom management}

\subsection{Management level of the school}

Management level and management quality of the school directly determines classroom management. What kind of school management has similar classroom management. the management of school needs a set of practical rules and regulations. Management should keep pace with the times, fully reflect "human nature", and attach importance to psychological communication and emotional communication between managers and managers.

\subsection{The management capacity of the teacher}

Teachers are the core of classroom management. The professional level, personal quality, work ability, teaching attitude, and organizational management experience of teachers directly determine the classroom management level. 


\subsection{Learning behavior of the student}

Students are not only the object of classroom management, but also the subject of classroom management. Students have clear learning goals, correct attitudes, solid basic knowledge, strong learning ability, standard behavior, strong self-regulatory management of the subject, classroom management is naturally standardized. On the contrary, there will be confusion in classroom management.

\section{Basic patterns of classroom management}

The basic mode of classroom management can be summed up and divided into three orientations: behaviorism orientation, humanism orientation and teacher effectiveness orientation.

\subsection{Behaviorism orientation}

The basic idea of the behaviorist orientation model is that the growth and development of students are determined by the external environment. The bad behavior they show in the classroom is either obtained through learning or because they have not learned the correct behavior. In classroom management, the teacher's responsibility is to strengthen appropriate behavior and eradicate inappropriate behavior. The typical behavior oriented classroom management models include Skinner model and Canter model.

Skinner mode is also called correction mode. He believes that human behavior is essentially a response to environmental stimuli. Whether the act can be sustained depends on the consequences. In classroom management, if teachers want to make students show appropriate behavior in the classroom, they must reward and strengthen appropriate behavior and ignore students 'bad behavior. In order to maintain a good classroom environment, teachers must do a good job in the following areas: clearly state the rules; Neglect of bad behaviour; Reward compliance with the rules.

The Canter model is also known as the decisive discipline model. This model is also a classroom management model under the guidance of behaviorism. It is different from the behaviorism model that emphasizes behavior strengthening. It hopes to effectively formulate and implement classroom order to manage subject discipline. Canter pointed out that many teachers believe that strong control is boring and cruel. It is wrong to believe that strong control is actually responsible to students and it is also effective. Teachers should use decisive discipline to manage the classroom, maintain good classroom discipline, and promote the development of students. Decisive discipline includes: prior statement and interpretation of requirements, expectations; Stick to your expectations and requirements to prompt students, but do not hurt their self-esteem; Use clear, calm, firm tone and eyes; Use non-verbal gestures to support speech requirements; Do not use threats and reprimands to influence students 'behavior; Repeat your request from time to time and do not upgrade to a reprimand.

\subsection{Humanism orientation}

Human-oriented classroom managers believe that students have their own decision-making capabilities and they can take primary responsibility for controlling their own behavior. In classroom management, teachers should not ask students to follow suit. Instead, they should pay attention to students 'needs, emotions, and initiative, and provide students with the best opportunity to explore a sense of belonging, achievement, and positive self-identification. In order to maintain a positive classroom environment; When problem behavior occurs, teachers should use communication skills to guide students to analyze the nature and consequences of the problem and solve the problem themselves. Typical humanistic classroom management models include W.Glasser model and H.Ginott model.

The Glasser model is called realistic therapy and control therapy. He believes that people have two basic needs, the need to love and be loved, and the need to want their own value to be recognized by themselves and others. Behaviour problems arise if these needs are not met. Students who do not meet these needs will have behavioral problems and are not responsible for themselves. 
In addition, he believes that students are rational and can control their own behavior. Therefore, teachers should not accept the excuse of students 'bad behavior, but should help students make good choices. Glasser proposed the basic procedures of realistic therapy: connecting students, correctly handling the behavioral problems faced by students, forming judgments, formulating plans, making commitments, not accepting excuses, and suffering natural consequences.

The Ginott model, also known as the wise information model, is a core concept of classroom management that emphasizes teachers 'use of wise ways to communicate with students in a harmonious manner. Ginott believes that discipline is formed a little bit. In the process of discipline formation, teachers should lead by example and put themselves in the other's shoes when communicating with students with behavioral problems. The other is to believe in students 'self-control and encourage students to manage themselves. Teachers and students should communicate in harmony: express "wise" messages, accept emotional catharsis instead of rejection, avoid labelling, use praise carefully, guide cooperation, and rationally express anger.

\subsection{Teacher effectiveness orientation}

The classroom management model of teachers 'efficiency orientation focuses on the improvement of teachers' classroom management skills. According to this orientation, classroom management mainly depends on the management skills of teachers; By training, the classroom management skills of teachers can improve the quality of classroom management. The typical classroom management models of teachers 'effectiveness orientation include the Gordon model and the Kuning model. Gordon mode is also called teacher effectiveness training mode. Kunin model. Is group management strategy for preventing and coping with misconduct.

\section{Main characteristics of the new generation of college students}

New generation of college students refers to Chinese citizens born after 2000 who entered the University. Its characteristics are:

\subsection{They like challenge rather than compromise}

They are willing to take on challenging, innovative, autonomous jobs that demonstrate value, develop talent and unleash potential. If they do repetitive work for a long time, they will feel bored. They like to be alone, willing to take responsibility, dare to face difficulties, but the ability of emotional control is insufficient, is not good at compromise and tolerance, and the team cooperation ability is also weak.

\subsection{Desperate for recognition and contempt for authority}

They hope to be recognized by organizations, leaders, and colleagues based on their own strength and performance. Awards and honors will have a great incentive for them, but if their performance is not recognized or encountered some setbacks in the workplace, they will become frustrated and free. They even give up directly: they worship idols, but they despise authority and will not unconditionally respect and obey superiors and predecessors; Willing to rely on hard work to achieve self-worth, but do not want to work to give up leisure and entertainment and education.

\subsection{E-communication and ignoring interpersonal}

They have a degree of cultural knowledge, are sensitive to new technologies, tools, ideas and practices, and have a faster grasp, but have difficulty in acquiring skills that need to be replicated and accumulated over time. They are more direct in dealing with people, tend to ignore the processing of interpersonal relationships, and are mainly unable to communicate with people through and through electronic network tools(mobile phones, computers, WeChat), The ability that face to face with people to deal with different groups of people in real society is weak.

\subsection{They like to immerse themselves in virtual worlds}

Today's urban children's very weak sense of reality is also the result of education. Our children 
were brought up to be replaced by all the real things. They only learned well, and our school did not provide children with the possibility to handle things. There was no activity except learning and remedial classes. The child lives in the modern computer world, the reality feeling is very weak. They experience reality in the virtual world, and there is a virtual sense in the real world. This is their characteristic.

\section{How to Manage Classroom in College Teaching}

\subsection{Creating a good teaching atmosphere}

It is generally believed that the classroom atmosphere is a psychological state formed by the teaching style of the teacher, the student's learning atmosphere, and the environmental effects in the classroom.

The positive classroom atmosphere is unity of calm and active, lively and deep, loose and strict organic. Classroom atmosphere influences students 'learning efficiency and personality development. Teachers are the organizers, leaders and managers of classroom teaching. The construction of a good classroom atmosphere requires teachers to organize and actively create. To create a good classroom atmosphere, teachers must first have the ability to operate the classroom. Classroom operation emphasizes the close connection between effective management and effective teaching in the classroom. The classroom operation ability is realized through the teacher's series of classroom learning management ability; Secondly, the ability of teachers to empathize. Empathy refers to the fact that when a person perceives a certain emotion of the other person, he can also experience the corresponding emotion, that is, he can feel his mood from the other person's point of view. In classroom learning management, teachers should have the ability to perceive emotional reactions, so that they can be in the position of students in terms of emotion and understanding, and they are mostly thinking about students. Therefore, empathy is a bridge between teachers and students. It can connect the intentions, views and emotions of teachers and students and create a good classroom atmosphere.

\subsection{Manage classroom discipline}

For every teacher, we should manage the students, especially the classroom. Whether we can manage the students well is directly related to our teaching achievements. While imparting knowledge, we all attach great importance to the management methods of the students. However, the development of society and the progress of the times require us to change, update the management methods, adapt to society, adapt to the times, and adapt to the characteristics of today's students.

First, improve the quality and ability of teachers themselves. Teachers are people in society and a mirror. From the teacher's body can not only reflect the contemporary society's knowledge, science and technology development situation, but also reflect the contemporary world Outlook, moral values, values and human truth. Whether teachers have prestige depends on whether they can win the students 'respect and conviction from the heart, and this in turn depends on the teachers' personal power. The quality of teachers is particularly important. This requires teachers to have extensive knowledge and superb business, so that students are convinced.

Second, the flexible use of teaching methods. According to the principles of classroom management, teachers should use their own wisdom to deal with the events in the classroom quickly and appropriately. The classroom evaluation language of management discipline must be aimed at students 'behavior and can not be used to insult students' personality. In general, if the student's behavior is conducive to learning, it is what you expect, and it must be clear that the type of behavior is your affirmation; On the contrary, if the student's behavior is unfavorable to learning, not what you expect, it should be criticized, but the criticism must also point to specific behavior.

\subsection{Understanding the needs of students makes teaching methods flexible}

Classroom learning management is not simply a matter of supervision and control. It is an 
important basis for classroom learning management to understand students 'various aspects, especially psychological needs. Only by adapting to the needs of students can the objective, content and method of teaching inspire students to learn more subjectively and effectively accomplish their learning tasks.

Teaching methods should be flexible and changeable, monotonous methods are easy to make students feel tasteless, tired of classroom teaching, and then there are violations of classroom discipline. Some teachers only explain the content of the teaching, instead of paying attention to teaching methods and teaching arts, so that the teaching process, which should make students feel relaxed and happy, has become a boring and boring activity that students hate. In this teaching situation, Students seem to be the audience excluded from teaching. One teacher is singing a monologue. Since students can not actively participate in education and teaching activities, classroom problems occur.

\subsection{Implement effective teaching measures to promote classroom learning}

Take effective teaching measures to guide students 'behavior into teaching activities and give full play to students' enthusiasm for learning. Only in this way the learning behavior in the classroom will increase and the problem behavior will decrease. For this reason, teachers must have clear teaching goals that are suitable for students 'psychological needs and academic levels. In order to achieve teaching goals, teachers must also provide effective guidance to students and use teaching materials and teaching methods that are appropriate in difficulty so that students are interested in the learning content itself. In this way, students will quickly become actively involved in learning.

Under the background of the rapidly changing times, the society has put forward more and more high demands on school education. In order to establish a positive classroom atmosphere conducive to teaching and learning, how teachers effectively improve the management of classroom learning will be the improvement of the quality of education and teaching, and thus have a profound impact on the future of the nation.

\section{References}

[1] Sina blog.http://blog.sina.com.cn/s/blog_8d3da5280100wuvq.html.

[2] 360 baike. http://baike.so.com/doc/1053530-1114453.html.

[3] Sina blog.http://blog.sina.com.cn/s/blog_566167c90102v53f.html.

[4] https://news.chazidian.com/news351389/.

[5] https://www.chsi.com.cn/jyzd/zazhi/zf/201111/20111123/262313827.html. 